\title{
The Role of Play at Home and in Kindergarten and Grade One: Parents' Perceptions
}

\author{
Shelley Stagg Peterson, Christine Portier, and Adam Murray
}

\begin{abstract}
A former elementary teacher in rural Alberta schools, Shelley Stagg Peterson is a professor in the Department of Curriculum, Teaching, and Learning at OISE/University of Toronto. She teaches graduate courses in elementary literacy and conducts research on young children's oral language and writing in play contexts in northern rural and Indigenous communities. Email: shelleystagg. peterson@utoronto.ca
\end{abstract}

Christine Portier is a postdoctoral fellow in the Department of Curriculum, Teaching, and Learning at OISE/University of Toronto. She is a former elementary teacher who now teaches graduate courses in elementary education and conducts research on young children's oral language and writing in play contexts in northern rural and Indigenous communities.

Adam Murray worked as a teacher in the city centre for Edmonton Public School Board for ten years. He is currently the principal of Kennedy Elementary School and Grimshaw Jr/Sr High School for the Peace River School Division and an advisory committee member for the Northern Oral Language and Writing through Play (NOW Play) project. As a public school educator, he is passionate about teaching children to read, and he continues to research and implement strategies that close the literacy gap of early learners.

This paper reports results of a survey of 208 parents and grandparents of children who attend kindergarten and grade one in northern rural communities in one Canadian province. Participants, whose education ranged from elementary school to university degrees, described play as an enjoyable physical activity involving running and being outdoors, and agreed that children are learning when they play. Our findings contrast with those of previous research, where parents' valuing of play as a learning activity correlated positively only with higher education levels.

Keywords: parent perceptions; play; learning; northern rural communities with information gathered through a survey of parents, most of whom had children in kindergarten or grade one in northern rural communities in a particular Canadian province. Research questions guiding the survey study were as follows:

- What are parents'/guardians'/grandparents' definitions of play, and do they see a connection between play and learning?

- What place do participants see for play at home, in kindergarten, and in grade one classrooms?

- In participants' views, what role should teachers and parents take vis-à-vis children's play?

In this article, we report the results of the survey. We begin with a review of the literature examining parents' and teachers' perspectives on play, and the constructs of play that informed the development of our survey. After reporting the findings, we draw conclusions and discuss implications for teachers and administrators. 


\section{Previous Research: Parents' and Teachers' Perspectives on Play}

In previous research, parents have presented a fairly uniform view of play as important for the amusement, socialization, or physical wellbeing of children (Badzis, 2003; Morrow \& Rand, 1991), appropriate for early learning in preschool programs (Qadiri \& Manhas, 2009) but not associated with academic learning as children get older (Badzis, 2003). In contrast, teachers have highlighted the motivational and active learning characteristics of play, suggesting that adults could contribute to children's learning through play (Chowdhury \& Rivalland, 2012; Christmas, 2005; Fogle \& Mendez, 2006; Rothlein \& Brett, 1987). These differing views have endured across decades and international borders, from 1987 (Rothlein \& Brett), when preschool children, their parents, and teachers in various socioeconomic and cultural communities in an American state were surveyed, to 2006 (Fogle \& Mendez), when African American mothers were surveyed using a parent play beliefs scale to capture their views on the academic benefits of play and the role of adults in children's play, to 2012 (Chowdhury \& Rivalland), when four mothers from a low socioeconomic neighbourhood in Bangladesh were interviewed. We did not find similar research investigating Canadian parents’ views on play or play-based learning.

Some of the research has shown sociocultural influences on parents' views of play. Chowdhury and Rivalland (2012), for example, concluded that, "play is greatly influenced by their [parents'] socio-economic position, personal experiences, educational background, and cultural nature of play. To the less educated or uneducated parents, children's academic achievement is more important than a leisure-time activity like play" (p. 120). These participating parents defined play as a leisure activity that should not distract children from their study in school at any grade, as they equated educational success with a route out of their socioeconomic conditions. In their homes, children played with each other, but parents generally did not enter into the children's play. A study examining the influence of education on parents' views, conducted in a province in Turkey, showed that primary-school educated parents were more likely than their university-educated counterparts to identify characteristics of play as an enjoyable activity rather than a learning activity (Pirpir, Er, \& Koçak, 2009).

An outcome of views separating play and learning in some jurisdictions, such as the USA (e.g., Bassok \& Rorem, 2014; Lynch, 2015; Miller \& Almon, 2009) and Australia (e.g., Freeman, 2015) is that primary teachers are being pressured to incorporate more formal reading instruction in place of play-based learning opportunities. These pressures appear to arise from a parental desire to give their children a "competitive edge ... [because parents] want to see results from educational expenditures, and while they do not mind seeing children paint and play as they might in a non-academic kindergarten, they would somehow rather see a rise in test scores" (Dombkowski, 2001, p. 545). These pressures and their influence on kindergarten and grade one classroom activities are critiqued in academic articles written about kindergartens in Hong Kong (e.g., Fung \& Cheng, 2012) and in the UK (e.g., Anning, 2015; Moyles, 2015).

\section{Development of the Survey: Understandings about Play}

Overarching all understandings of play used to develop the survey items is the notion that play is a culturally constructed concept. All themes around play must be viewed as particular to certain sociocultural groups within particular historical and geographical contexts (Göncü, Jain, \& Tuermer, 2006). Indeed, questions in our parent survey study reflect a view of play that Cannella and Viruru (2004) argue "represents the biases and values of Western societies that privilege explorations with objects and monocultural notions of progress" ( $p$. 104). For example, definitions of play as child centered and supportive of children's learning and overall development were influential to our survey item development. Proponents of a view of play as child initiated and enjoyable to children agree that play provides a context where children feel free to explore, try out hypotheses, and set their own goals and rules for their play (Smith, 2009; Wood, 2013). The notion of choice is both sociocultural and individual, because the possible choices reflect the cultural views of play within homes, communities, and schools, yet individual children take up these potential roles and activities in varying ways (Broadhead, Wood, \& Howard, 2010).

Our decision to ask questions about the roles that adults take in children's play also reflects views of play as an activity supporting children's cultural and overall learning. Recognizing these cultural influences on survey development, we created open-ended questions such as "When you think of the word play, what comes to mind?" and "What do your children like to play at home?" in an attempt to create space for parents to present alternate perspectives of play. We also asked questions about how frequently participants thought children should be playing at home, in kindergarten, and in grade one to gain an understanding of cultural views on the value of play in these contexts.

Influential perspectives on play and learning, the topic that was of greatest interest to teachers and thus the central focus of the survey, are detailed below. 


\section{Play Provides a Context for Learning and Development}

This view of play stems from Lev Vygotsky's (1967) social constructivist theory, of which one tenet is that

play is the source of development and creates the zone of proximal development. Action in the imaginative sphere, in an imaginary situation, the creation of voluntary intentions and the formation of real-life plans and volitional moves_all appear in play and make it the highest level of preschool development. (p. 16)

Pretend/dramatic play is considered especially important to children's learning because of the abstract thinking that is involved, where children attach meaning to everyday objects, a process similar to the symbolic representation of ideas involved in reading and writing (Bodrova \& Leong, 2009; Roskos \& Christie, 2009; van Oers, 2014). In addition to encouraging abstract thinking, play contexts promote children's problem solving and hypothesis testing (Whitebread, 2010). It is not only cognitive learning that is developed through play, but children's physical coordination and muscular strength as well (Power, 2000). Pyle and Bigelow (2014) propose three categories of classroom approaches to play-based learning in their profile of three kindergarten teachers: "play as peripheral to learning, play as a vehicle for social and emotional development, and play as a vehicle for academic learning" (p. 392). Our survey included a forcedchoice question asking whether children learn when they play, followed by an open-ended question requesting participants to explain their answer or provide examples. We did not want to influence participants' responses to this question by providing examples of children's learning.

\section{Adult Roles in Children's Play}

Researchers and theorists are divided in their views on how much and in what ways teachers, parents, and other adults should enter into children's play. Cautioning against intervention, Pellegrini and Galda (1993) use their research to show that adult intervention can put constraints on the sophistication of children's language during play. Bennett et al. (1997), however, question the assumption that when children make their own choices, learning becomes a much more powerful activity. Their research shows that the quality of childcentered learning depends on the range of choices available, the amount of interaction with more knowledgeable peers and adults, the provision of supportive resources, and the potential for activity to be connected to worthwhile learning. Bodrova and Leong (2009) also argue that adult intervention can raise the level of children's play toward more abstract mental representations that support children's cognitive development and their literacy learning. This perspective appears to have been accepted, to a large extent, by mainstream parents and teachers in contemporary Western cultures. Peter K. Smith's (2009) work shows that adults are inclined to enter into children's play, encouraging certain kinds of play and channelling children's play toward educational outcomes. Survey questions about teachers' and parents' roles in children's play arose from this research regarding adult intervention in children's play. The item choices invited parents to rate parent and teacher interventions so that a range of perspectives might be represented in the survey results.

\section{Methods \\ Participants and Their Northern School Division}

Participants were 205 parents and three grandparents, most of whom (88.9\%) were female. Parents/grandparents were sent surveys via their children, who each were attending one of eight elementary schools in the Eagle Hills School Division in northern Canada. Eagle Hills School Division covers a large geographic area and serves more than 10 communities. The average population of schools in the division is 200 students. Average class sizes are 15 in primary grades and slightly less than 20 in the upper elementary grades. Economic activities in Eagle Hills communities are based in agriculture, resource extraction, and forestry, requiring a trade-qualified workforce that is augmented with general labourers and small business entrepreneurs that cater to these industries. Parents in Eagle Hills School Division communities are heavily involved in their children's curriculum and have high expectations for meaningful and engaging educational experiences for their children.

All participants had children, with $94 \%$ having at least one child of kindergarten or grade one age, and 59\% of participants had college or university education, $31 \%$ had secondary school education, $7 \%$ had trades training, certification, or licensing, and 3\% identified elementary education as their highest level of education. All participants completed the survey independently without reading assistance. 


\section{Development of Survey}

Survey questions were developed to provide information that the teachers and administrators in the participating school division would find useful to inform their classroom practices and communications with parents. Additionally, our item development was carried out with the following goals in mind: (1) presenting items clearly so that the participants would interpret them as researchers intended; (2) generating valid information that would address the research questions; and (3) ensuring that completing the survey was not an onerous and off-putting task.

We piloted the survey by asking four graduate students who were parents of young children to complete the survey. The students kept track of the time it took to complete the survey and provided suggestions for rewording two questions to clarify their intent.

The school division's early learning/supports and services coordinator organized and carried out the distribution and collection processes. She emailed principals and kindergarten teachers of eight elementary schools in the Eagle Hills School Division to inform them about the study and invite their participation. Potential participants were sent paper copies of the surveys through the school division courier system. Each school then sent the surveys home via children in the kindergarten and grade one classrooms in the school. Students brought the completed surveys to their teachers. The school secretary collected the surveys and then sent them to the school division's central office. Return rates ranged from $100 \%$ in one of the smaller schools to $24 \%$ in the largest school. The average return rate was approximately $50 \%$ per school.

\section{Data Analysis}

We used inductive analysis methods for open-ended questions and questions in which participants had been asked to check all responses that applied to them (Strauss \& Corbin, 1998). This involved highlighting key words and phrases, combining these words and phrases into groups, and creating labels to describe what the words and phrases within each group had in common. For example, when participants described the play activities in which their children engaged at home, some wrote playing outside, some wrote play on the trampoline, some wrote swimming, some wrote quadding (riding all-terrain vehicles), and others wrote riding bikes. We grouped these responses together and categorized them as Physical/Outdoor Play because we felt that this label captured the characteristics common to all the play activities mentioned. We then calculated the percentages of words or phrases within each category and displayed the results in frequency tables.

For survey questions $6,7,8$, and 11, we used Likert scale (close-ended) questions to gather a range of responses. We calculated averages (out of four) for questions that asked participants to indicate how often they thought that particular activities should take place (never, rarely, sometimes, or often; strongly disagree, disagree, agree, or strongly agree) at home, in kindergarten, and in grade one classrooms. We calculated frequencies (in percentages) for these responses as well. The frequencies for each of these questions required large separate tables, so we condensed the data and simplified our tables by using mean values (see Tables 4 and 6 ). We are aware of the concerns around the use of mean values with Likert-type scales. For example, although we asked participants to rank their responses along a scale of never-rarely-sometimes-often, the intervals between the values on our scale may not have been presumed equal by the participants (Blaikie, 2003; Jamieson, 2004), and thus statistical tests (e.g., for significance) cannot be performed on mean values. Instead, we used the mean values to convey more information in fewer tables. We also used them to indicate where participants' responses tended to fall in the given range.

To discuss our results in relation to previous research in other countries, we also compared the responses of the participants who had secondary and postsecondary education to those with elementary education, but did not conduct statistical analyses because the number of participants with elementary education was very small (3\%).

\section{Findings}

Views of Play

In response to question 3 (When you think of the word play, what comes to mind?), participants most frequently described play as a physical activity that involves running and being outdoors and is enjoyable or fun (see Table 1). For example, some participants noted that when children play, they "go to the park" and "build snow forts and snow men." Children's play, according to participants, also involves "running, jumping, [being] outside, and [getting] exercise and fresh air." 
Play was also frequently described as a social activity (e.g., "interacting with peers" and "children verbally interacting with each other") and as an activity where children create something and use their imaginations to pretend (e.g., "dressing up," "making crafts," and "unstructured, imaginative interaction").

Table 1: How Participants Defined Play (in Percentages)

\begin{tabular}{|l|c|}
\hline \multicolumn{1}{|c|}{$\begin{array}{c}\text { Definition } \\
\text { (N = 661 } \text { phrases) }\end{array}$} & Percentages \\
\hline physical activity & 27.2 \\
\hline enjoyable/fun & 23.9 \\
\hline social activity & 21.8 \\
\hline create/imagine & 16.6 \\
\hline play with games/toys & 10.5 \\
\hline
\end{tabular}

When participants were given a list of activities in question 5, they generally agreed that children are playing when engaged in all these activities, with the exception of using apps on electronic devices. Outdoor games, such as tag and hide-and-seek, were almost unanimously defined as examples of children's play, with dressing up, imagining or pretending, and building with blocks or LEGO also supported by almost all participants (see Table 2).

Table 2: Activities Participants Considered To Be Play (in Percentages)

\begin{tabular}{|lc|}
\hline \multicolumn{1}{|c|}{ Activities } & Participants Who Said "Yes" \\
\hline take part in outdoor game (e.g., tag, hide and seek) & 99.0 \\
\hline dress-up & 97.6 \\
\hline build with blocks or LEGO & 97.1 \\
\hline imagine or pretend & 97.1 \\
\hline climb, crawl, etc., on large equipment & 95.7 \\
\hline act out stories with puppets & 95.6 \\
\hline sing / dance / make music with instruments & 93.7 \\
\hline make things out of materials (play dough, macaroni, etc.) & 92.3 \\
\hline pour, measure, etc., with sand and water & 91.8 \\
\hline use board games & 91.0 \\
\hline put puzzles together & 90.8 \\
\hline participate in organized sports & 88.9 \\
\hline use apps for children on electronic devices & 48.3 \\
\hline
\end{tabular}

\section{Play and Learning}

When asked directly in question 10 whether children are learning when they are playing, all participants agreed that they are. In their written explanations about the specific learning that occurs through play, they most frequently referred to the development of social skills, such as "learning to share and play fairly with others" and "appropriate ways to handle different situations." Participants also explained that when children play, they develop conceptual understandings that span across discipline areas, noting, for example, that children learn "counting," "colours," "literacy + numeracy," "the nature of the world," and "how things work." Participants also wrote about the development of cognitive processes (e.g., "problem solving," "cause and effect," and "critical thinking"), as well as the development of creativity and a sense of imagination. They wrote that the physical activity of play contributes to a child's gross and fine motor skill development, because children learn "coordination," "balance," "dexterity," and "hand-eye coordination." With some frequency, participants also mentioned that because children have choices and feel success in play activities, they gain self-confidence and independence through play. One parent described learning through play as "joyous experimentation with the world around them." Table 3 shows the percentages of the types of responses that participants gave to the open-ended question. 
Table 3: Participants' Descriptions of How They Consider Children To Be Learning in Play Activities (in

Percentages)

\begin{tabular}{|l|c|}
\hline \multicolumn{1}{|c|}{$\begin{array}{c}\text { Types of Learning During Play } \\
\text { (N = 596 } \text { phrases) }\end{array}$} & Percentages \\
\hline develop social skills & 29.2 \\
\hline develop conceptual understandings across disciplines & 21.4 \\
\hline develop thinking processes & 11.1 \\
\hline enhance creative and imaginative thinking & 11.1 \\
\hline develop motor skills (fine and gross) & 10.9 \\
\hline motivational and enjoyable & 5.7 \\
\hline develop self-confidence and independence & 3.7 \\
\hline enhance communication skills & 3.7 \\
\hline good for health (physical and emotional) & 3.2 \\
\hline
\end{tabular}

Time for Play at Home, in Kindergarten, and in Grade One

In response to questions 6-9, all participants agreed that children should have time to play in kindergarten classrooms, at home, and in daycare settings, though less frequently in grade one than in the other contexts. Participants generally agreed that children should be engaging frequently in all identified activities, with the exception of using apps, at home and in kindergarten and grade one (see Table 4). Participants indicated that playing with toys should occur less frequently in grade one than at home or in kindergarten. Kindergarten was identified as the context where children should most frequently play with sand.

Table 4: Participants' Views of How Often Children Should Engage in Play Activities at Home and in Kindergarten or Grade 1 Classrooms (1=Never; 2=Rarely; 3=Sometimes; 4=Often)

\begin{tabular}{|l|c|c|c|}
\hline & \multicolumn{3}{|c|}{ Means (Out of 4) } \\
\hline Type of Activity & Home & Kindergarten & Grade 1 \\
\hline play (in general) & 3.93 & 3.74 & 3.43 \\
\hline toys & 3.83 & 3.71 & 3.43 \\
\hline apps & 2.83 & 2.69 & 2.74 \\
\hline climbing & 3.50 & 3.64 & 3.56 \\
\hline LEGO & 3.79 & 3.73 & 3.51 \\
\hline pretend & 3.81 & 3.79 & 3.64 \\
\hline materials & 3.71 & 3.83 & 3.66 \\
\hline art & 3.79 & 3.86 & 3.80 \\
\hline sand & 3.40 & 3.62 & 3.34 \\
\hline
\end{tabular}

Play Activities at Home

In response to question 12 (What do your children like to play at home?), participants listed playing with LEGO more frequently than any other activity (in 116 responses), although the category that we placed it in (Building) was the fourth most frequent overall category (see Table 5). Physical/outdoor play was by far the most frequently identified overall category of children's play activities at home. Creative activities (e.g., colouring / making crafts / drawing) and playing games or doing puzzles were also frequently identified activities. 
Table 5: Participants' Descriptions of Play Activities in Which Children Engage at Home (in Percentages)

\begin{tabular}{|l|c|}
\hline \multicolumn{1}{|c|}{$\begin{array}{c}\text { Type of Play } \\
\text { (N = 1457 descriptions) }\end{array}$} & Percentages \\
\hline physical or outdoor play & 27.9 \\
\hline creating & 13.9 \\
\hline games and puzzles & 13.7 \\
\hline building & 10.7 \\
\hline pretending or imagining & 9.9 \\
\hline playing with toys & 9.1 \\
\hline technology or media & 8.3 \\
\hline playing with family and pets & 4.1 \\
\hline dancing or singing & 2.4 \\
\hline
\end{tabular}

\section{Teachers' and Parents' Roles}

In response to question 13 (What do you do when your children are playing?), the majority of participants said they provide materials for their children to play with, observe what their children are doing, ask questions about what their children are doing, join in and play with their children, and show or tell their children things to teach them something new. Most participants agreed that these parental roles should be mirrored in kindergarten and grade one classrooms. Fewer participants indicated that they do not intervene in children's play, other than to ensure that the children do not get hurt. Table 6 shows how strongly participating parents agreed with specific contributions to children's play in kindergarten and grade one.

Table 6: Participants' Level of Agreement about Teachers' Roles While Children Are Playing in Kindergarten and

Grade 1 Classrooms (1=Strongly Disagree; $2=$ Disagree; $3=$ Agree; $4=$ Strongly Agree)

\begin{tabular}{|l|c|}
\hline Teacher Role & $\begin{array}{c}\text { Mean Frequency of } \\
\text { Agreement (Out of 4) }\end{array}$ \\
\hline use children's play interests in a lesson & 3.61 \\
\hline provide materials for children to play with & 3.56 \\
\hline ask children questions about what they are doing & 3.54 \\
\hline show or tell children things to teach them something new & 3.53 \\
\hline observe and assess children's learning & 3.39 \\
\hline join in and play with the children & 3.32 \\
\hline $\begin{array}{l}\text { keep track of time to make sure children have a chance to play at all } \\
\text { centres }\end{array}$ & 3.15 \\
\hline make sure children don't get hurt but leave them alone otherwise & 2.85 \\
\hline
\end{tabular}

\section{Participants'Education Levels and Perspectives on Play}

A comparison of responses by participants' education levels showed no differences. Education level was not related to participants' views on play. For example, the elementary-educated participants thought that grade 1 children should be engaged in play closer to "often" for both pretend play (mean $=3.8)$ and playing with materials (mean $=3.6)$, as did the more highly educated participants (means of 3.64 and 3.66 respectively).

\section{Conclusions and Implications}

Results of our study show that views of parents and grandparents, whose education backgrounds ranged from elementary school to university, aligned with teachers' and researchers' (e.g., Bodrova \& Leong, 2009; Whitebread, 2010) perspectives. Parents indicated that play is an activity that should often be part of a kindergarten program, and sometimes, if not often, part of grade one programs. Parents 
gave examples of a wide range of play options for their children, with outdoor/physical play and creative play valued to a greater extent than playing with technology or digital media. Additionally, participating parents indicated that they value their own interactions with children and felt that teachers should be actively involved in classroom play activities. While it is advisable to conduct further research of a qualitative nature in order to contextualize these survey findings, given that many parents explicitly identified various types of learning that occurs through play and indicated that children should be engaging in play activities at least sometimes, it appears that they see a role for play-based learning in kindergarten and grade one. The specific types of learning align with Pyle and Bigelow's (2014) categorization of social/emotional learning and academic learning. Participants also included children's creativity and their health and physical development as play-based learning.

Our survey results go against the grain of previous surveys of parents (e.g., Christmas, 2005; Fogle \& Mendez, 2006), which found that views of parents with postsecondary education were more likely to align with teachers' and researchers' views than were those of parents with lower education levels. Further research is needed to explore the influence of education and other sociocultural variables on parents' perspectives, given the differences in survey results. Further research could also explore principals' perceptions of play and learning and forms of support that they provide to teachers who implement play-based learning. Concomitantly, teachers' perspectives and experiences could be examined to understand forms of support that teachers receive and would like to receive from school and school district administrators and from parents as they implement play-based teaching and learning practices.

In reflecting on other research that has found low support among parents for play-based learning, from a school principal's perspective (one of the authors), it is understandable that parents might be concerned if their children said that all they did was play in school. Yet our survey shows that these parents are in the minority. As an explanation for negative parental attitudes toward play-based learning, it is possible that teachers are more likely to remember or feel pressure from parents who express negative sentiments about the play activities in the classroom. It is also possible that some teachers are unsure how to explain to parents the learning that occurs through play-based activities. As teachers shape play activities to support learning outcomes, they might consider how they will clearly articulate this learning to parents, including how play supports and strengthens learning, and the roles that teachers take in supporting children's learning through play. School and school division administrators also play a role in articulating their support for play-based learning in formal and informal communication with parents of students in the school.

\section{References}

Anning, A. (2015). Play and the legislated curriculum. In J. Moyles (Ed.), The excellence of play (4th ed.; pp. 3-13). Maidenhead, England: McGraw Hill Open University Press.

Badzis, M. (2003). Teachers' and parents' understanding of the concept of play in child development and education (Unpublished doctoral dissertation). University of Warwick, Coventry, England.

Bassok, D., \& Rorem, A. (2014). Is kindergarten the new first grade? The changing nature of kindergarten in the age of accountability. EdPolicyWorks Working Paper Series No. 20. Charlottesville, VA: University of Virginia. Retrieved from: http://curry.virginia. edu/uploads/resourceLibrary/20_Bassok_Is_Kindergarten_The_New_First_Grade.pdf

Bennett, N., Wood, L., \& Rogers, S. (1997). Teaching through play: Teachers' thinking and classroom practice. Bristol, PA: Open University Press.

Blaikie, N. (2003). Analysing quantitative data. London, England: SAGE.

Bodrova, E., \& Leong, D. J. (2009). Play and early literacy: A Vygotskian approach. In K. A. Roskos \& J. F. Christie (Eds.), Play and literacy in early childhood: Research from multiple perspectives ( $2^{\text {nd }}$ ed.; pp. 185-200). New York, NY: Routledge.

Broadhead, P., Wood, E., \& Howard, J. (2010). Understanding playful learning and playful pedagogies: Towards a new research agenda. In P. Broadhead, J. Howard, \& E. Wood (Eds.), Play and learning in the early years (pp. 177-185). Thousand Oaks, CA: SAGE.

Cannella, G. S., \& Viruru, R. (2004). Childhood and postcolonization. New York, NY: RoutledgeFalmer.

Chowdhury, N. N., \& Rivalland, C. (2012). Value of play as an early learning instrument in Bangladesh context: A socio-cultural study. 
Australasian Journal of Early Childhood, 37(4), 115-122.

Christmas, J. (2005). Is it OK to play? Perceptions of play in a small rural primary school. In K. Hirst \& C. Nutbrown (Eds.), Perspectives on early childhood education: Contemporary research (pp. 141-149). Stoke-on-Trent, England: Trentham Books.

Dombkowski, K. (2001). Will the real kindergarten please stand up?: Defining and redefining the twentieth-century US kindergarten. History of Education, 30(6), 527-545.

Fogle, L. M., \& Mendez, J. L. (2006). Assessing the play beliefs of African American mothers with preschool children. Early Childhood Research Quarterly, 21(4), 507-518.

Freeman, M. (2015, January 27). Homework in kindergarten sends the wrong message. Sunday Age. Retrieved from: http://www.theage. com.au/comment/homework-in-kindergarten-sends-the-wrong-message-20150127-12yfm6.html

Fung, C. K. H., \& Cheng, D. P. W. (2012). Consensus or dissensus? Stakeholders' views on the role of play in learning. Early Years, $32(1), 17-33$.

Göncü, A., Jain, J., \& Tuermer, U. (2006). Children’s play as cultural interpretation. In A. Göncü \& S. Gaskins (Eds.), Play and development: Evolutionary, sociocultural, and functional perspectives (pp. 155-178). Mahwah, NJ: Lawrence Erlbaum.

Jamieson, S. (2004). Likert scales: How to (ab)use them. Medical Education, 38(12), 1212-1218.

Lynch, M. (2015). More play please. The perspective of kindergarten teachers on play in the classroom. American Journal of Play, 7(3), $347-370$.

Miller, E., \& Almon, J. (2009). Crisis in the kindergarten: Why children need to play in school. College Park, MD: Alliance for Childhood. Retrieved from: http://files.eric.ed.gov/fulltext/ED504839.pdf

Morrow, L. M., \& Rand, M. K. (1991). Promoting literacy during play by designing early childhood classroom environments. The Reading Teacher, 44(6), 396-402.

Moyles, J. (2015). Starting with play: Taking play seriously. In J. Moyles (Ed.), The excellence of play (4 ${ }^{\text {th }}$ ed.; pp. 14-24). Maidenhead, England: Open University Press.

Pellegrini, A. D., \& Galda, L. (1993). Ten years after: A reexamination of symbolic play and literacy research. Reading Research Quarterly, 28, 162-175.

Peterson, S. S., Forsyth, D., \& McIntyre, L. (2015). Balancing play-based learning with curricular mandates: Considering the views of northern Canadian teachers and early childhood educators. Canadian Children, 40(3), 40-47.

Pirpir, D. A., Er, R. K., \& Koçak, N. (2009). Comparison of attitudes of parents having children in early childhood period related to play. Procedia Social and Behavioral Sciences, 1, 933-938.

Power, T. G. (2000). Play and exploration in children and animals. Mahwah, NJ: Lawrence Erlbaum.

Pyle, A., \& Bigelow, A. (2014). Play in kindergarten: An interview and observational study in three Canadian classrooms. Journal of Early Childhood Education, 43, 385-393.

Qadiri, F., \& Manhas, S. (2009). Parental perception towards preschool education imparted at early childhood education centers. Studies on Home and Community Science, 3(1), 19-24.

Roskos, K. A., \& Christie, J. F. (2009). Play and literacy in early childhood: Research from multiple perspectives (2 ${ }^{\text {nd }}$ ed.). New York, NY: Routledge. 
Rothlein, L., \& Brett, A. (1987). Children's, teachers', and parents' perceptions of play. Early Childhood Research Quarterly, 2(1), $45-53$.

Smith, P. K. (2009). Pretend play and children's cognitive and literacy development: Sources of evidence and some lessons from the past. In K. A. Roskos \& J. F. Christie (Eds.), Play and literacy in early childhood: Research from multiple perspectives $\left(2^{\text {nd }}\right.$ ed.; pp. 3-19). New York, NY: Routledge.

Strauss, A., \& Corbin, J. (1998). Basics of qualitative research: Techniques and procedures for developing grounded theory (2 $2^{\text {nd }}$ ed.). Thousand Oaks, CA: SAGE.

van Oers, B. (2014). Cultural-historical perspectives on play: Central ideas. In L. Brooker, M. Blaise, \& S. Edwards (Eds.), The SAGE handbook of play and learning in early childhood (pp. 56-66). London, England: SAGE.

Vygotsky, L. S. (1967). Play and its role in the mental development of the child. Soviet Psychology, 5, 6-18. (Original work published in 1933)

Whitebread, D. (2010). Play, metacognition, and self-regulation. In P. Broadhead, J. Howard, \& E. Wood (Eds.), Play and learning in the early years (pp. 161-176). Thousand Oaks, CA: SAGE.

Wood, E. (2013). Play, learning, and the early childhood curriculum. London, England: SAGE. 